\title{
Effectual Planning on Affordable Housing-The Case of Nanjing
}

\author{
Francis Deng Clement ${ }^{1}$, Yunning Cheng ${ }^{2}$, Zhang Hong1 \\ ${ }^{1}$ Dept. of Architecture, Southeast University, Nanjing, China \\ ${ }^{2}$ Dept. of Landscape Architecture, Southeast University, Nanjing, China \\ Email: francisdeng1@gmail.com,bzhangh555@aliyuan.com,ccyn999@126.com
}

How to cite this paper: Clement, F.D., Cheng, Y.N. and Hong, Z. (2018) Effectual Planning on Affordable Housing-The Case of Nanjing. World Journal of Engineering and Technology, 6, 63-82.

https://doi.org/10.4236/wjet.2018.62B007

Received: April 6, 2018

Accepted: May 19, 2018

Published: May 22, 2018

\begin{abstract}
This research scrutinize how the Chinese system applied to reduces cost effectiveness in order to curves housing affordability for the purpose of land prices for the social housing popularly known as low cost social housing schemes as the government took measures throughout the years, however the paper describes the key characteristics of Chinese urban planning and design system, subsidies to social rented housing producers are being cut and equates this with practice within Chinese spectrum. The paper describes the key characteristics of the national planning, as per the recent trends housing policy on-affordability, this planning system assists overall housing requirements and how it has been adapted. It explains the new arrangements the government has put into place to lower land prices for social housing and argues that this represents provide and expand the supply of good quality housing units; make housing more affordable and readily available; promote economic diversity in residential neighborhood; help households build wealth; and promote balanced metropolitan growth.
\end{abstract}

\section{Keywords}

Effectual Planning, Nanjing-China, Affordable Housing, Housing Stocks, Household and Urbanization

\section{Introduction}

Research on affordable housing through the years has been the subject of concern particularly housing policy in China since 2006. Irrational in decision-making of affordable housing resulted in great social risk and reduce the positive effectiveness. The research proposal concentrations on the planning field, especially on space decision-making of location and layout which aims to 
improve the role of planning in macro and meso equal towards rational space decision-making of affordable housing.

\section{Shelter Situation Analysis}

\subsection{Basic General Data}

Geography and Administration China is the fourth largest country in the world with a total area of 9,596,961 sq km. China is comprises of 23 provinces, 5 autonomous regions, and 4 municipalities. Besides two special administrative regions- Hong Kong and Macau, Chinese Communist Party became the ruling party from 1949 and there are eight registered small parties controlled by CCP. National People's Congress has the highest legislative power.

\subsubsection{Demography and Health [1]}

In 2008, China has a population of $1,328,030,000$ (not including Hong Kong Macau, Taiwan) with a natural growth rate of $5.08 \%$ and an urbanization rate of about $44 \%$, among which there are 683,570,000 male and 644,450,000 females. According to sample survey the average household size is 3.16 persons perhousehold. So the total number of household is about 420 millions. The fertility rate is 1.77 births per women. Mortality rate of under 5 is $6.7 \%$. Life expectancy at birth is 69 . As to the age structure, 0 - 14 years accounts for $20.5 \%, 15$ - 64 years $71.5 \%, 65$ years and over $7.9 \%$ as a great breaking forth.

\subsubsection{Economy}

China's economy during the past 30 years has changed from a centrally planned system that was largely closed to international trade to a more market-oriented economy that has a rapidly growing private sector and is a major player in the global economy. Since 1991, the average annual growth rate of GDP is around $10 \%$. Measured on a purchasing power parity (PPP) basis that adjusts for price differences, China in 2009 stood as the second-largest economy in the world after the US, although in per capita terms the country is still lower middle-income. Measured in US dollars using nominal exchange rates, China's GDP in 2013 was $\$ 9.3$ trillion, about 55\%. Economic development has been more rapid in coastal provinces than in the interior, and approximately 200 million rural laborers and their dependents have relocated to urban areas to find work, population and the permanent migrant population reflects China's regional development patterns in less developed regions [2]. The government vowed to continue reforming the economy and emphasized the need to increase domestic consumption in order to make China less dependent on foreign exports for GDP growth in the future. Engel's Coefficient of Urban Households 2008 is $37.9 \%$, the largest expenditure of urban household is still on food as per Figure 1 illustrates per capital living expenditure of urban household.

1) Household Expenditure

Engel's Coefficient of Urban Households 2008 is 37.9\%, the largest expenditure of urban household is still on food. 


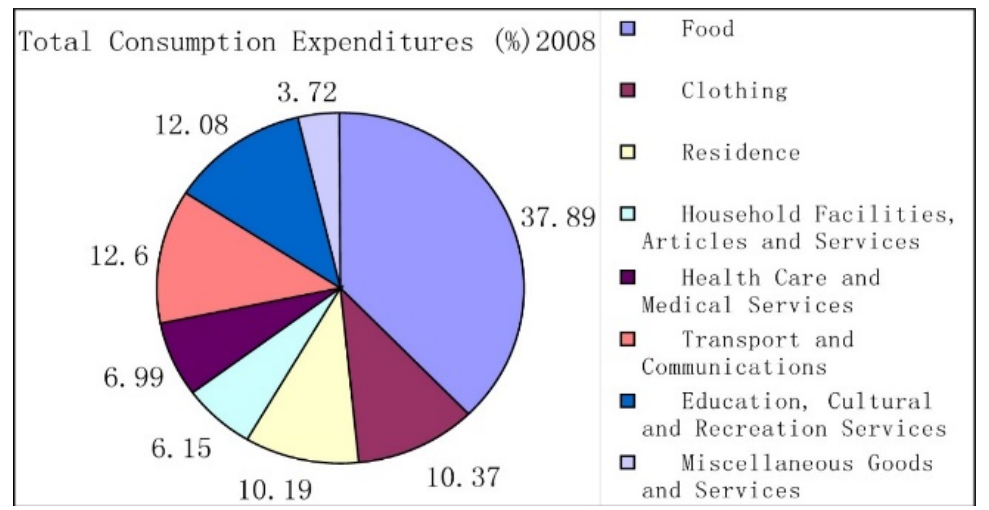

Figure 1. Per Capita living expenditure of urban households (2008).

\section{2) Income Distribution}

According to data of World Bank, Gini coefficient of China in 1960s is 0.17 0.18 , the data in 1980s $0.21-0.27$. Since 2000, Gini coefficient of China exceeds the alert line of 0.4 and keeps increasing year by year. The data of 2007 has been up to 0.48 . And the ratio of the annual income of the highest $20 \%$ population to the lowest $20 \%$ population is 10.7 .

3) Poverty

In a long term, China defined the poverty line just due to the adequate food and clothing. From 1986, the poverty line began to include lowest income population (786 yuan to 1067 yuan). And in 2009, the central government again improved the poverty line to about 1300 yuan, which expanded the population below the poverty line to 40.07 million (3.0\% of the total population). Undoutly, through 60 years efforts, China has solved several million-people's food and clothing, which is a big achievement. However, with the complicated urbanization and industrialization, the poverty alleviation is facing new challenges. For example, the registered unemployment rate is $4.2 \%$ of total labor forces, which doesn't include those workers who lost their jobs in the process of State-owned enterprise reformation and those migrant workers from rural.

4) Social Class

Reforms started in the late 1970s to China's socialist market economic system, which changed the closed social structure "workers, peasants and Intellectuals" to a more multiple and fluent social structure. Presently, social structure is composed of ten levels of social stratums, some of which with rich resources, some of which with poor resources. Compared to economic development, social development is seriously lagged, the current hierarchical structure "is only a prototype, not yet a fair, open and reasonable modern social structure, the existence of structural factors lead to social crisis" an important mechanism by which a positive identity is maintained [3].

\subsection{Shelter Related Fact and Figures}

\subsubsection{Access to Shelter}

Housing stock, Floor area per person While China has entered a period of rapid 
urbanization, every year a large number of urban houses were built, which make the rapid growth of China's urban housing stock. At the end of 1997, China has a total floor area of residential building of 3.62 billion square meters; while at the end of 2008, the data reached 12.7 billion square meters, an increase of 9.1 billion square meters. The period of 2000-2005 is an acceleration period of construction of houses.

From 2005, yearly increasing number of floor areas of urban residential buildings maintained at $5-7$ million. If each house by 90 square meters to calculate, there are about 140 million urban housing units. These factors result in substantial growth in per capita housing floor space as these distinctions seen in Figure 2.

\subsubsection{Housing Deficit}

However, due to a large number of speculative and investment behavior in purchasing houses, which linked to the high prices of the houses in some big cities, every year there were only $3 \%-4 \%$ of households receiving housing improvements. The number of households living in a unit in the form of joint family and living in incomplete unit is around $25 \%-30 \%$. also measure regional geography by specifying whether households are located in the designated areas[4]. In 2009, the number of low-income families with per capita housing construction area of less than $13 \mathrm{sq} \mathrm{m}$ is 15.4 million.

\subsubsection{Housing Standard}

A house with kitchen, bathroom, living room, bedroom and basic well-equipped could be called a set of houses. In 1990, the rate of sets of houses was less than $40 \%$, then the rate has increased annually to $55.98 \%$ in 2002 , up to $80.6 \%$ in 2005. Currently, according to state regulations, Low-cost rental housing area was controlled at less than 50 square meters/set, affordable housing below 60 square meters/set, medium and small housing below 90 square meters/set, and those exceeding 144 square meters/set could be called big-houses.

\subsubsection{Ownership (Formal and Informal)}

In 2007 , houses with own property accounted for $82.2 \%$ of urban housing (the

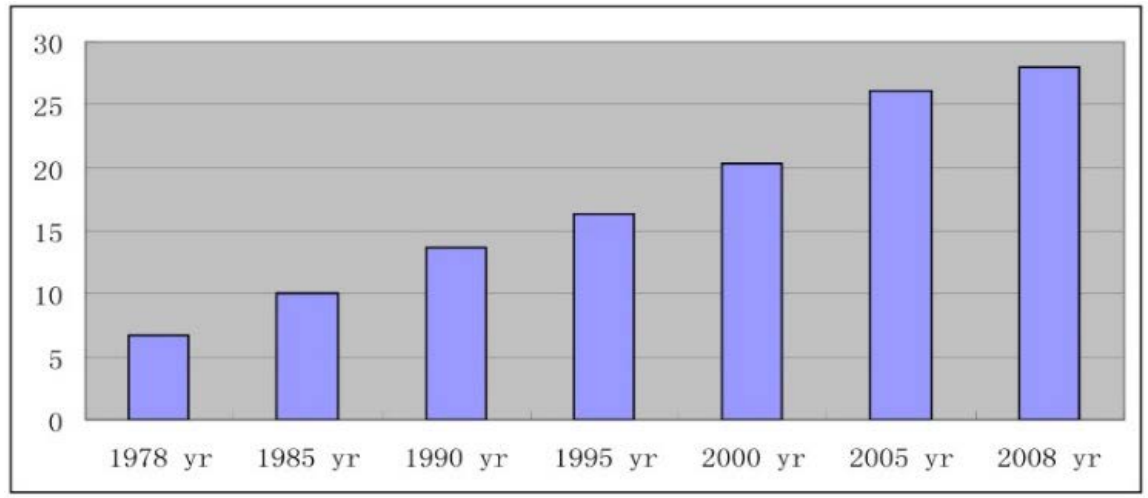

Figure 2. Urban residential building Floor area per person $\left(\mathrm{m}^{2}\right)$. 
highest proportion of housing is reform housing-34.2\%, followed by the commercial housing-32.1\%, the original private houses accounting for $12 \%$, affordable housing accounting for 3.9\%), rental housing accounted for 15\% (Private rental accounting for $8 \%$, public rental houses accounting for $7 \%$ ), and $2.8 \%$ houses' property right were not clear. The first reason of rapid privatization of urban housing in China is a large scale of the sale of public housing during the process of housing reform. The second is due to the housing market over the past decade. Compared to those countries with more mature housing markets, public rental housing in China accounts for very small percent. It is difficult for low-income and middle-low income families, newly graduates and rural migrant workers to get appropriate houses.

\subsubsection{House Price to Income Ratio}

Shanghai YIJU Real Estate Research Institute released a report, which said the ratio of China's house price to income in 2009 reached a new record of 8.03, and the ratio of Beijing, Shanghai, Shenzhen and Hangzhou were more than 14.In 1997-2003, the ratio was kept relatively stable, the average of which was 6.2. From 2003 to 2007, with house prices grew faster than disposable income, the ratio significantly increased to 7.44 in 2007. In 2008, with a series of real estate control policies, the ratio markedly dropped to 6.78. In 2009, with the recovery of the real estate market to overheat in some areas, newly built commercial housing prices nationwide rose 25 percent, which create a new record of house price to income ratio-8.03.

However, the land management philosophy also contributed to the high prices as a major reason. Since 2005, the government pays great attention to low-cost and affordable housing, which land could be got by allocation, and the policy commercial housing of low price, which land could be got by sale with conditions.

\subsection{Access to Affordable Housing}

\subsubsection{Types of Affordable Housing}

Presently, there are three common types of affordable housing.

The first is low-cost rental public housing, which land is obtained by allocation. Low-cost rental housing is to meet the living need of those lowest- income households that have difficulties in buying commercial housing.

The second is low-income affordable housing (commonly called affordable housing), which land is also obtained by allocation. Low-income affordable housing is a kind of commercial housing under the control of the government to meet the need of low-income households. It is provided by the market, but must be sold with low-profit price.

The third is limited-price commercial housing which land use is obtained by allocation or sale with the condition of unit area and price. Presently, most limited-price commercial housing is resettlement housing to meet the needs of households in the urban and rural demolition. Besides the three types of afford- 
able housing, in some city industrial parks, there had been some rental-type housing responding to migrant workers in government guidance and market operation. And with the gradual expanding of affordable housing policy, in some cities public rental housing have broken through the current range of restrictions on low-cost housing to young people, migrant workers and lower-middle income households.

\subsubsection{Affordable Housing Stock}

Low-cost Rental Public Housing: It is reported by ministry of Housing Urban and Rural Development that at the end of 2006, total of more than 547,000 households improved the housing conditions through the low-cost rental public housing system. Among them, the recipients of subsidized rental housing accounted for 167,000 households, getting the rental houses accounted for 77,000 families, the recipients of rent deduction accounted for 279000 , other means to improve the living conditions 24,000. In 2007, the number of households enjoying the policy of low-cost rental public housing increased 680,000. In 2008, the number increased 2,500,000.

Low-income Affordable Housing: From 1997 to 2009, the total sale areas of Affordable housing are 0.41 billion sq $\mathrm{m}$ which accounts for only $3.2 \%$ of total floor areas of residential building. See Figure 3.

The sale areas of the affordable housing reached high point in 2001-2003 and has been declining over the same period the price of commercial housing was climbing higher and higher.

\subsubsection{Housing Policy}

Since the 1990s, there is the tendency of the evolution of the housing policy from a welfare allocation to a market economy, and then to over-biased industrial policies, and presently to public policy.

1) Phase 1 (mid-1990s to 2000):

In-depth reform of the housing system to promote multi-level housing supply system The state gradually increase the rent reform in order to speed up the sale of welfare housing as an opportunity to foster the real estate market, then thoroughly stop housing distribution at the end of 20th century. It is clearly stated to establish multi-level urban housing supply system mainly made up of affordable housing.

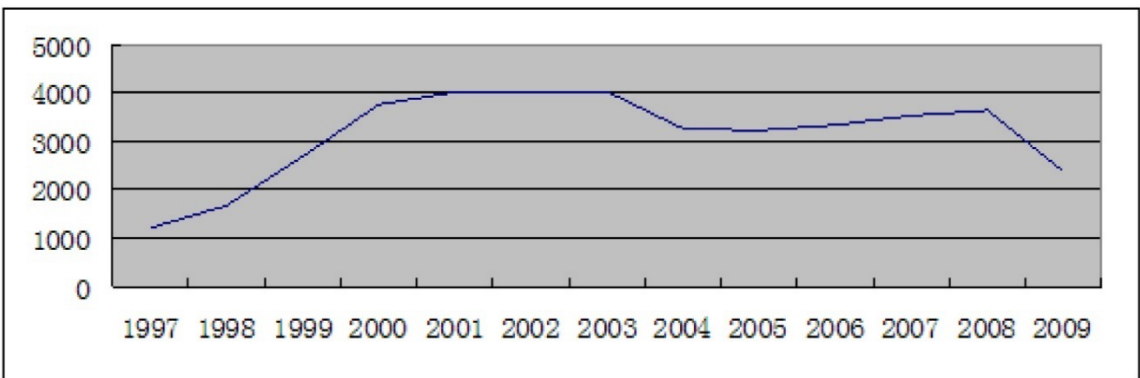

Figure 3. Indicating areas of sales low income affordable housing $\left(1000 \mathrm{~m}^{2}\right)$. 
2) Phase II (2000-2004):

The commercialization of housing supply into the lead, and the market 2 structure has become more unreasonable.

To promote real estate development, the state issued a series of tax incentives which brought the rapid expansion of housing demand in the short period of time. In addition to active buyers demand, there were lots of passive demand caused by demolition increased considerably unhealthy situations appeared while the rapid development of the real estate industry. In Jiangsu Province, villas and luxury apartments increased markedly excessive, the supply of affordable housing is increasingly inadequate.

3) Phase III (2003-2005): began to strengthen the housing security system, while the effect was still extremely limited.

By strengthening the housing security system to balance the unhealthy development of the real estate market had made some success. Affordable housing, low-rent housing re-gained attention. The demolishing scale was controlled to ease the rapid growth of housing needs. However, the scope of the policy of affordable housing and low-rent housing is narrow, which effect on balancing the real estate is still limited.

4) Phase IV (2005-2009): Strengthening the regulation and guidance, the housing market in the dynamic adjustment.

A series of new policy on low-income affordable housing and low-cost rental public housing were released, which stated the local government responsibilities in the housing security. While the "common housing" was admitted by public opinion, the estate development concepts are being adjusted.

5) Phase V (2010 ):

Continuing to strengthen the regulation and guidance, also expand the coverage of affordable housing policy, concerning affordable housing planning.

It is clearly pointed out to promote public rental housing which made the housing supply system covering the middle-low income people and floating population. The planning on affordable housing is paid much more attention and the local governments are requested to prepare 2010-2012 construction of affordable housing and "the twelfth five years" planning on housing. This is the first time for central government to ask for planning on construction of affordable housing which demands a comprehensive content on predicting the amount, the guidance on spatial distribution, supporting policies and measures, and so on.

\subsection{Actors in Shelter Delivery and Their Role}

Table 1 renders a clear descriptive of various actors and role played on shelter delivery.

\section{Organization}

The specialty of Urban Planning and Design in Southeast University keep ahead 
Table 1. Actors in shelter delivery and their roles.

\begin{tabular}{|c|c|c|}
\hline Activities & Actors & Roles played \\
\hline \multirow[t]{2}{*}{$\begin{array}{l}\text { Development } \\
\text { organization } \\
\text { mechanism }\end{array}$} & government & $\begin{array}{l}\text { make development plans, formulating relevant } \\
\text { policies, financial operation }\end{array}$ \\
\hline & $\begin{array}{l}\text { Government } \\
\text { sectors }\end{array}$ & $\begin{array}{l}\text { Taking the relevant research to assist } \\
\text { decision-making of government, and } \\
\text { make management adjustments; make } \\
\text { sector plans or relevant plans }\end{array}$ \\
\hline \multirow[t]{3}{*}{$\begin{array}{l}\text { Real estate } \\
\text { development } \\
\text { mechanism }\end{array}$} & $\begin{array}{l}\text { Government } \\
\text { sectors }\end{array}$ & $\begin{array}{l}\text { Choosing development timing, regulate } \\
\text { and control land supply, constructing } \\
\text { infrastructure and public facilities, } \\
\text { provide public service }\end{array}$ \\
\hline & $\begin{array}{l}\text { Real estate } \\
\text { Enterprise }\end{array}$ & $\begin{array}{l}\text { Decision-making of specific real estate's } \\
\text { development mostly in the level of micro } \\
\text { level, but some powerful companies } \\
\text { could exert their influence to } \\
\text { government in micro level or meso level }\end{array}$ \\
\hline & $\begin{array}{l}\text { Development } \\
\text { agency with } \\
\text { government } \\
\text { background }\end{array}$ & $\begin{array}{l}\text { play the role of a financing platform with the } \\
\text { help of market forces to promote state-owned } \\
\text { land development, carry out construction and } \\
\text { operation management of some public } \\
\text { housing or welfare facilities }\end{array}$ \\
\hline \multirow[t]{3}{*}{ Planning mechanism } & Government & Organizing master plan \\
\hline & $\begin{array}{l}\text { Planning } \\
\text { management sector }\end{array}$ & $\begin{array}{l}\text { Organizing zoning and urban design and } \\
\text { other plan in need, examine and approve } \\
\text { detailed planning, planning management }\end{array}$ \\
\hline & $\begin{array}{l}\text { Planning } \\
\text { institution } \\
\text { or company }\end{array}$ & $\begin{array}{l}\text { Provide planning service for government and } \\
\text { its sectors or real estate enterprise }\end{array}$ \\
\hline Research mechanism & $\begin{array}{l}\text { Planning } \\
\text { institution or } \\
\text { university or } \\
\text { personal }\end{array}$ & $\begin{array}{l}\text { Some are engaged in research according to the } \\
\text { need of government or enterprise, some take } \\
\text { research independently }\end{array}$ \\
\hline
\end{tabular}

in such fields as follows: Urban Design, Urban Central District, Protection Planning, Residential District, etc. We have a research group with an emphasis on affordable and indemnificatory housing, residential space morphology, housing development and planning mechanism. Our school has a long-term good relationship with the local government sectors such as urban planning bureau and provincial construction department. So we are sensitive on hot spot issues and have chances to gain the research basic data and materials. And by efforts, there are possibilities for us to be the expert consultants of government on the issue of affordable housing.

The school of architecture also has a planning institution with the highest qualification grade and I am a National Registered City Planner registered in it. So we have chances to be involved in planning practice on shelter.

Finally, as an associate professor, I can tutor my graduates to do master degree 
thesis on affordable housing. As the teacher in charge of the course for undergraduate-Residential Environment, I can integrate the related knowledge into the teaching content. As a independent researcher, I have the ability to publish my research production to exert widespread and far-reaching impact.

\section{Shelter Problem}

The problem embodied in three aspects. The first is the policy on affordable housing, which involves the coverage of population enjoying the policy of affordable housing, financial guarantee, application and handing back institution, efficient management and maintenance institution. The second is the planning mechanism, which includes the coordinate institution on the planning organization and the cooperate institution on the planning implementation. The third is the space decision-making of affordable housing. The two former aspects are shown in Figure 4.

Type I: the earliest resettlement areas that have blended into the master city area. Type II: the resettlement areas that scatter evenly in the new city district. Type III: the resettlement areas on the edge of the master city area. We selected Yincheng Huayuan (10 ha, about 800 households), Taiping Huayuan (40 ha, about 3500 households) and Xianju Yayuan (40 ha, about 3200 households) for our deeper investigations. They represent the three above- mentioned types and

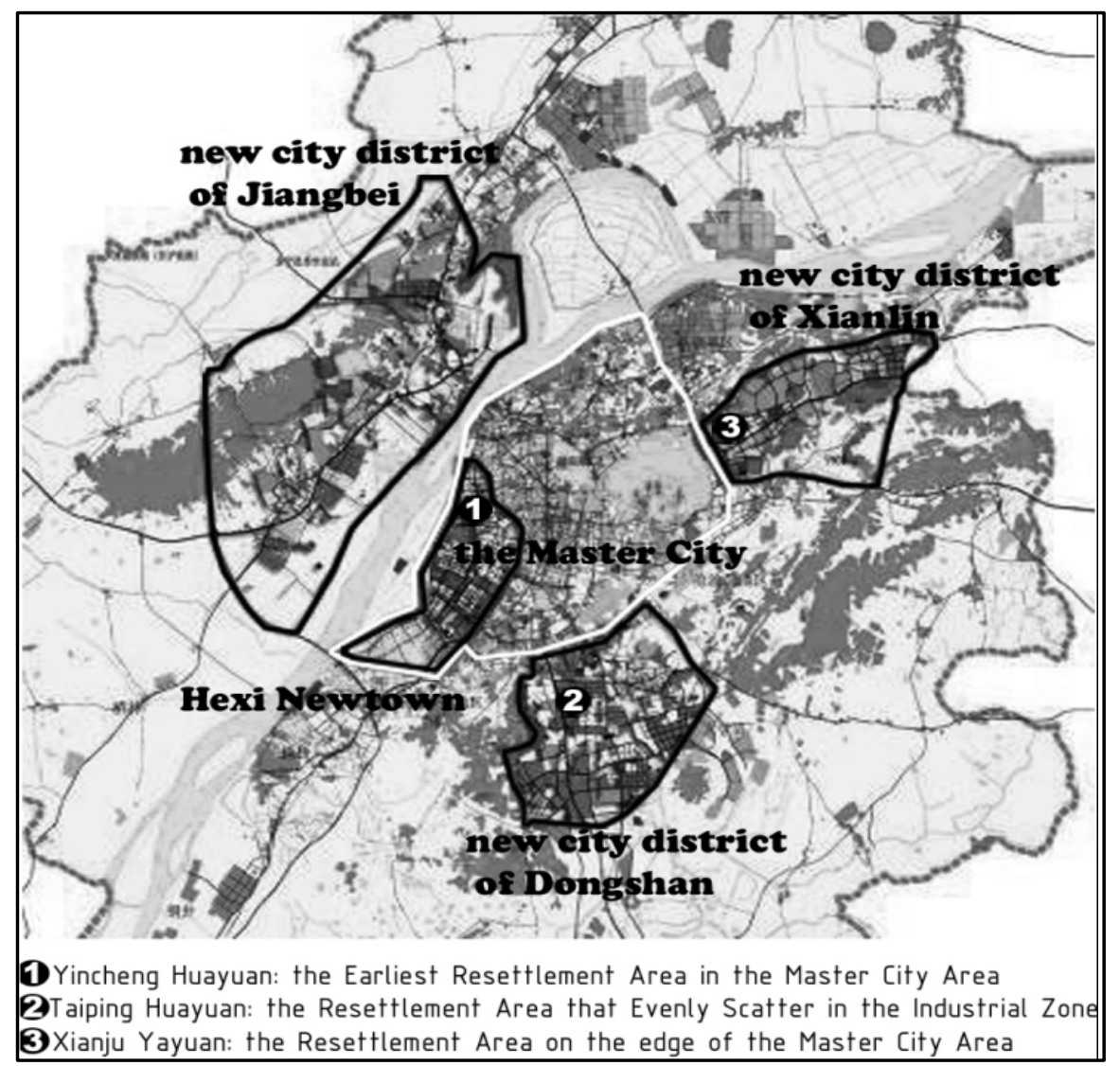

Figure 4. The location of three typical affordable house areas for land lost farmer. 
they are able to show comprehensively the basic conditions of existing resettlement areas of Nanjing responsibilities of government, while the third is the important research field which planner should exert their wisdom and influence, and planner also should put forward suggestions on planning mechanism in a comprehensive view.

\subsection{An Actual Investigation on Three Typical Affordable Houses' Area for Land-Lost Farmers Resettlement}

\subsubsection{General Introduction}

Since the 21st century, Nanjing has launched its developing frame of "one-new town, three-new city districts" to push the urbanization process actively. Such development process involves a large number of land requisitions and developments. To compensate those farmers, government constructed affordable houses as represented in Figure $\mathbf{5}$ their resettlement area. In the primary phase of investigation, we stressed general surveys and elementary investigations in the resettlement areas for land-lost farmers and found that three spatial types of resettlement areas occurred with the historical process of urbanization.

\subsubsection{Analysis}

Based on the investigations and analyses of the resettlement areas for land-lost farmers, we have managed to classified the living conditions and employment environments provided by cities into the following factors: house quality and interior environment of residential area, sharing degree of public facilities and urban conveniences, children's educations, employment supports, compensation and guarantee polices. We have analyzed the relationships between these influential factors and the general adaptations of residences by combining with the psychological status of these residents. See Table 1. In according with the investigations, the general conditions of Taiping Huayuan in Jiangning Industrial District are more favorable because the industrial park provided them appropriate employment and they can share the same public facilities with the nearby

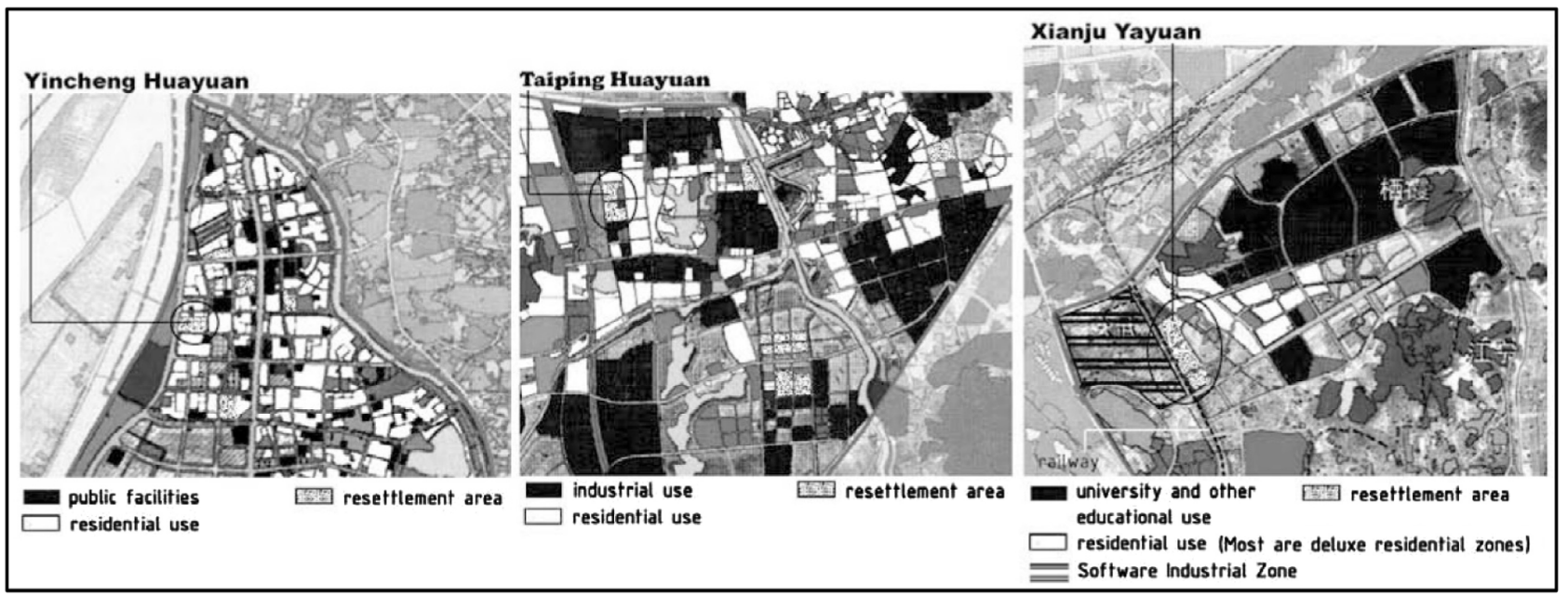

Figure 5. The surrounding of three typical affordable house area for land lost farmer. 
communities. Considering the residents in Yincheng Huayuan of Hexi newtown, they hold stronger inimical emotions for the lowest compensations, but they have been adaptive to urban life gradually for they have enjoyed the conveniences in urban life, especially their children can get the good education. The general adaptation conditions of Xianju Yayuan are worse, which lies in the east margin of the master city, also the very edge area of the new city district area of Xianlin. Most of the surrounding communities are deluxe residential zones like villas. However, its public transportation is very inconvenient, its public facilities hold low sharing degree with the surrounding communities and the employment opportunities are not suited for those land-lost farmers. Comparing with their high rate of satisfaction with physical conditions of the area, the adaption result is ironical as per illustration Table 2.

\subsubsection{Conclusions}

Four conclusions could be drawn based upon the above study:

- Reasonable compensation standard and good residential interior environment are the primary basic conditions to guarantee the respectable life of land-lost farmers, yet not enough to promote long-term development of them.

- Employment supports around resettlement areas, which have greater pertinence, will dispel sufficiently the inimical emotions of land-lost farmers brought by their passive urbanizations.

- To share the same living environment and urban conveniences, public equipment and facilities, especially educational facilities, will improve life qualities and the possibility of later generation's up-ward social mobilities.

- Distributions of resettlement areas in appropriate scale and with ordinary residential areas nearby are beneficial for farmers to communicate with

Table 2. Analysis on influential factors for adaptations of residents.

\begin{tabular}{|c|c|c|c|c|}
\hline Importance & $\begin{array}{l}\text { Influential } \\
\text { Factor }\end{array}$ & $\begin{array}{l}\text { Type I } \\
\text { (Yincheng } \\
\text { Huayuan) }\end{array}$ & $\begin{array}{l}\text { Type II } \\
\text { (Taiping } \\
\text { Huayuan) }\end{array}$ & $\begin{array}{c}\text { Type III } \\
\text { (Xianju Yayuan) }\end{array}$ \\
\hline \multicolumn{5}{|c|}{ House quality and interior environment of residential area } \\
\hline \multicolumn{5}{|c|}{ Sharing degree of public facilities and urban conveniences } \\
\hline \multicolumn{5}{|c|}{ Children's educations } \\
\hline \multicolumn{5}{|c|}{ Employment supports } \\
\hline \multicolumn{5}{|c|}{ Compensation } \\
\hline \multicolumn{2}{|c|}{ Psychological status of residents } & $\begin{array}{c}\text { Passive } \\
\text { adaptation, } \\
\text { stronger } \\
\text { inimical emotion }\end{array}$ & $\begin{array}{l}\text { Passive } \\
\text { adaptation, } \\
\text { weaker } \\
\text { inimical } \\
\text { emotion }\end{array}$ & $\begin{array}{l}\text { Passive } \\
\text { adaptation, } \\
\text { stronger } \\
\text { inimical } \\
\text { emotion }\end{array}$ \\
\hline \multicolumn{2}{|c|}{ General adaptation } & $\begin{array}{c}\text { Get } \\
\text { adapted slowly }\end{array}$ & Basically adapted & Worst adaptation \\
\hline
\end{tabular}


urban residences and blend themselves into cities in the long term. area or remote site seems unable to resolve, the last decision is usually made by the administrative order and land value is always taken into consideration much more than others.

The right-above figure show the location of affordable housing in Nanjing (not include LuHe, JiangNing, PuKou) 2000-2007. The most majority of affordable housing located around ring-road of major city with inconvenience of public transport and imperfect public faculties. Some sites even are in the urban public green space which result in no loss of land value but have no public facility and infrastructure at all. The dilemma embodies on such aspects as follow:

- Land supply: It's difficult to balance the government's appeal on land value and the people's appeal on their own development. Government usually chooses those lands with the lowest value to construct affordable houses.

- Site location: It's difficult to guarantee the affordable house area's appropriate relationship with the whole urban system during the rapid urbanization process. There isn't professional urban planning method that can help government carry through a rational choice. To those people living in affordable houses, land value-oriented development and disregarding of the site location actually are some kind of special exclusion, which will result in social equity. They will feel strong social depriving which will increase their inimical emotion and the social risk.

\subsection{Irrational Space-Decision of Affordable Housing}

\subsubsection{The Dilemma of Site Location}

From space exclusion to social inequity there are controversies on the site location of affordable housing. One insists that in order to show the government's concern, the site should be central area with high shown in Figure 6.

Level of public services; another view that affordable housing should not influent real estate market, therefore remote site with low land value is proper. The paradox of affordable housing site is in the central Ring Road.

\subsubsection{The Unreasonable Layout of Affordable Housing: From Space Isolation to Social Segregation}

Low-income households and land-lost farmers with low education level are vulnerable groups of society. They need the urban support very much. However, government takes liberties with the layout of affordable housing which result in a very occasional social result. Naturally, government actors also pursue their own self interests in adjudicating policies [5]. The unreasonable layout embodies on such aspects as follow:

Affordable house area's scale: Some of the existing affordable housing have a large scale (20,000 - 40,000 inh), with public facilities self-contained and isolated from the outside communities, the public services' quality of which is worrying.

Community structure: Some of suburban affordable housing's neighborhoods are villas (luxury houses). Despite of short distance between each other, they 


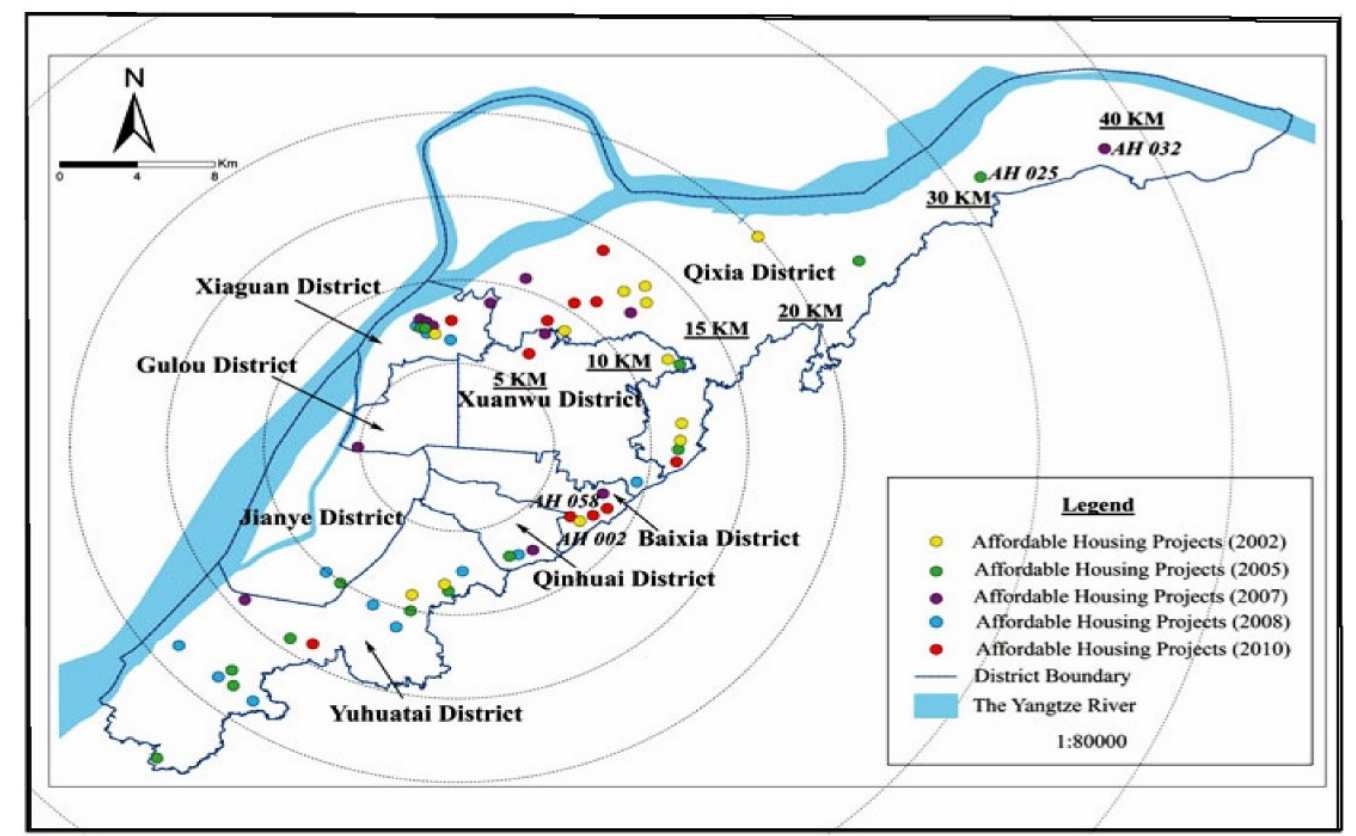

Figure 6. Affordable housing locations in main city district, Nanjing.

don't communicate at all. Of course, they can't share the same facilities. The above two unreasonable layouts will result in one result which is space isolation, and then result in social segregation. Those residents don't communicate with other communities, while they couldn't enjoy the same living conditions and public facilities (especially children's school) as other citizens, they will become closer and closer. The community atmosphere is always out of control with lots of safety problems, which is not conducive to a harmonious society.

\subsubsection{The Deep Cause of Those Irrational Space-Decision: A Narrow Goal Oriented Affordable House's Construction}

At present, the goal of affordable housing construction is still just to meet the basic living needs of those households, meanwhile to draw the domestic needs. But their long-term sustainable development is neglected. The situation of inconvenient transportation, difficulties of finding employment and imperfect public services couldn't be improved in a long term. The lack of upward social mobility and later generational social mobility of these populations is not conducive to the safety of these communities and their long-term development.

\subsection{Current Action and Problem of Planning System for Affordable Housing}

1) Planning Mechanism

The above table show planning effect is absent in important decision-making process of affordable housing. How to intervene the space reserve by formal planning regulations on site location and layout? How to play role in land supply and following public facilities construction? How to give powerful suggestion on employment space, community development and public service? What planning 
mechanism can make planning force into a negotiation, cooperation process?

2) Planning Method.

\subsection{Challenges in the Future}

The time of huge scale construction of affordable housing is coming According to "houses construction plan in future three years, 2009", there are 5,810,000 low-cost rental public housing, and 3,900,000 low-income affordable housing that will be constructed in three years. If the plan come true, then by 2011 there will be 0.26 billion $\cdot \mathrm{m}^{2}$ low-cost rental public housing and 0.35 billion. $\mathrm{m}^{2}$ low-income affordable housing, which take up $11.47 \%$ and $8.46 \%$ of whole newly houses areas.

1) New policies will bring out more varieties of affordable housing

It is gratifying that in 2010 the central government formulates a series of policy to promote the construction of affordable housing, this acts government judgment [6] which are "Notice on firmly curbing the surge in housing prices in some cities, by State Council", "Notice on the promotion of stable and healthy development of the real estate market, by State Council Office", "Guidance on accelerating the development of public rental housing, by ministry of housing and urban-rural development". The types of affordable housing will become more various. The local governments are urged to promote the construction of public rental housing to meet the housing demand of the middle-low income people and floating population. The space needs of those different populations have their own characters. How to take these varieties into consideration is a big challenge when planning.

2) Government improved the demand on the planning of affordable housing

In 2010, another important policy was released that is "Notice on making plan for affordable housing, by ministry of housing and urban-rural development". The planning on affordable housing is paid much more attention and the local governments are requested to prepare 2010-2012 planning on construction of affordable housing and "the twelfth five years" planning on housing. This is the first time for central government to ask for planning on construction of affordable housing which demands a comprehensive content on predicting the amount, the guidance on spatial distribution, supporting policies and measures, and so on.

\section{Proposal for Change and Improvement}

\subsection{Goal Improvement}

Goal 1: Long term sustainable development

To avoid space exclusion and to promote long term development of those people, both forecasting need amount of affordable housing and making rational location of affordable housing are necessary. Enough land should be reserved, with appropriate location on employment, public facility, transportation and so on. 
Goal 2: Comprehensive social benefit

To avoid space isolation and to promote social integration, a harmonious community structure is necessary. Large scale, isolated islands should be avoided, instead of healthy and harmonious communities with external positive effects.

\subsection{Suggestions on Planning Mechanism}

1) Make clear the relationship between affordable housing plan and the conventional plan system.

Based on current planning system, special plan for affordable housing should be added. Special plan for affordable housing could be connected to micro and meso conventional planning system easily, furthermore, including targeted survey and research on location and layout. Planning period should be synchronous with the five-year immediate plan of comprehensive planning.

2) Planning organizing institution focusing on guidance and coordination.

Due to the complexity of affordable housing, the ideal system is the establishment of specialized agencies responsible for its planning, construction and management, which is also professional on its guidance and coordination. For example, the responsibilities exerted by the Hong Kong housing authority and housing department has made a significant guarantee of success on public housing construction.

3) Cooperating institution of planning implementation.

For the successful implementation of the plan, cooperating institution of related sectors is necessary to promote the support of the urban environment, including employment support, transportation support, timely construction of public facilities and other municipal facilities, and timely delivery of reserves of land.

\subsection{Improvement of Planning Method}

1) Macro level: Sitelocation technique-responding to Goal 1.

- Planning technique path

In China, land value is very important for local government. The biggest challenge for site location is to balance the economic value of land and livability degree for those populations. So, the evaluations of land should be on these two aspects. By evaluating the economical value of land, those lands of high value could be avoided. By evaluating the livability degree for those population, those lands of high livability degree could be chosen preferentially and Point accessibility surfaces based on (a) out-degrees, (b) step us with opportunities for analysis and modeling that are quite different from those available in configurational forms all find implicit expression in this work [7].

- Land evaluation system on livability degree for those population

Considering the related public facilities, educational facilities, transportation, employment environmental, two level of indicators are set up to assess the liva- 
bility degree as two final steps are necessary [8]. According to the importance of indicators, different weights are assigned. We have finished a special plan for affordable housing in Luhe District, Nanjing. Aland evaluation system on livability degree for those populations was used in the plan. See Table 3. The role of evaluation system is not only to do analysis, more importantly, is to provide a dialogue platform between planning institute, public sectors and the government. On this basis, a more fluid exchange of the relevant participants could be easily reached much more.

- Land evaluation system on livability degree for those population

Considering the related public facilities, educational facilities, transportation, employment environmental, two level of indicators are set up to assess the livability degree. According to the importance of indicators, different weights are assigned. We have finished a special plan for affordable housing in Luhe District, Nanjing. A land evaluation system on livability degree for those populations was used in the plan. See Table 4.

The role of evaluation system is not only to do analysis, more importantly, is to provide a dialogue platform between planning institute, public sectors and the government. On this basis, a more fluid exchange of the relevant participants could be easily reached much more.

2) Mesolevel: Layout technique-responding to Goal 2

- Reasonable community structure

Special plan for affordable housing should be linked to the regulatory plan. The

Table 3. Planning system on affordable housing.

\begin{tabular}{|c|c|c|c|c|}
\hline $\begin{array}{l}\text { Planning } \\
\text { level }\end{array}$ & $\begin{array}{l}\text { Planning } \\
\text { Type }\end{array}$ & Planning contents & Organizer & Role and problem \\
\hline \multirow[b]{2}{*}{ Macro } & $\begin{array}{c}\text { Housing } \\
\text { Construction } \\
\text { Plan } \\
\text { Annual }\end{array}$ & $\begin{array}{l}\text { To forecast the amount of } \\
\text { various types of housing } \\
\text { construction, the amount of } \\
\text { land needed and financial } \\
\text { expenditure plan } \\
\text { Annual amount of various } \\
\text { Types of housing }\end{array}$ & $\begin{array}{l}\text { Municipal } \\
\text { government } \\
\text { and its housing } \\
\text { sector } \\
\text { Municipal }\end{array}$ & $\begin{array}{l}\text { Role: adjust the housing structure and fulfil the financ- } \\
\text { ing. Focus on low-cost public rental housing and low } \\
\text { income affordable housing, the for cast about which is } \\
\text { exact usually. } \\
\text { Problem: for cast about limited-price commercial }\end{array}$ \\
\hline & $\begin{array}{l}\text { Housing } \\
\text { Construction } \\
\text { Plan }\end{array}$ & $\begin{array}{l}\text { Construction, annual } \\
\text { amount of land needed and } \\
\text { financial expenditure plan }\end{array}$ & $\begin{array}{l}\text { And its housing } \\
\text { sector }\end{array}$ & Housing isn't exact; lack of research on site location \\
\hline Meso & \multicolumn{4}{|c|}{$\begin{array}{l}\text { Problem: in this level, the reisnoinstitutional planning of affordable housing. } \\
\text { Lack of research on layout, no zoning regulation on affordable housing. }\end{array}$} \\
\hline Micro & $\begin{array}{l}\text { Detailed } \\
\text { planning }\end{array}$ & $\begin{array}{l}\text { Settlement plan, Houses } \\
\text { design, public building } \\
\text { design, landscape design }\end{array}$ & $\begin{array}{l}\text { Construction } \\
\text { sector or real } \\
\text { estate company }\end{array}$ & $\begin{array}{l}\text { Role: guide the construction of an affordable house area } \\
\text { Problem: lack of user oriented design }\end{array}$ \\
\hline
\end{tabular}


Table 4. Land evaluation system on livability degree for those population in special plan for affordable housing.

\begin{tabular}{|c|c|c|c|c|c|c|c|c|}
\hline No & Indicators & Weight & & Factors & Assessm & nt criteria & & \\
\hline . & & $\begin{array}{l}\text { Weight } \\
\text { of } \\
\text { indicator }\end{array}$ & $\begin{array}{l}\text { Weight } \\
\text { of } \\
\text { factor }\end{array}$ & & $\begin{array}{l}\text { First } \\
(100)\end{array}$ & $\begin{array}{l}\text { Second } \\
(75)\end{array}$ & $\begin{array}{l}\text { Third } \\
(50)\end{array}$ & $\begin{array}{l}\text { Forth } \\
(25)\end{array}$ \\
\hline \multirow[b]{2}{*}{1} & \multirow{2}{*}{ Public facilities } & \multirow[b]{2}{*}{$25 \%$} & $12.5 \%$ & $\begin{array}{l}\text { Community } \\
\text { center }\end{array}$ & $\begin{array}{l}\text { Has been } \\
\text { constructed }\end{array}$ & On construction & $\begin{array}{l}\text { In the five-year } \\
\text { immediate plan }\end{array}$ & $\begin{array}{l}\text { No } \\
\text { immediate } \\
\text { plan }\end{array}$ \\
\hline & & & $12.5 \%$ & $\begin{array}{l}\text { Basic } \\
\text { community } \\
\text { center }\end{array}$ & $\begin{array}{l}\text { Has been } \\
\text { constructed }\end{array}$ & On construction & $\begin{array}{l}\text { In the five-year } \\
\text { immediate plan }\end{array}$ & $\begin{array}{l}\text { No } \\
\text { immediate } \\
\text { plan }\end{array}$ \\
\hline \multirow[b]{2}{*}{2} & $\begin{array}{l}\text { Educational } \\
\text { facilities }\end{array}$ & $25 \%$ & $15 \%$ & $\begin{array}{l}\text { Nine-year } \\
\text { compulsory } \\
\text { education } \\
\text { facilities }\end{array}$ & $\begin{array}{l}\text { Has been } \\
\text { constructed in } \\
\text { reasonable } \\
\text { radius }\end{array}$ & $\begin{array}{l}\text { On construction } \\
\text { in reasonable } \\
\text { radius }\end{array}$ & $\begin{array}{c}\text { In the } \\
\text { five-year } \\
\text { immediate plan }\end{array}$ & $\begin{array}{l}\text { No } \\
\text { immediate } \\
\text { plan }\end{array}$ \\
\hline & & & $10 \%$ & $\begin{array}{l}\text { Kindergarten, } \\
\text { high school }\end{array}$ & $\begin{array}{l}\text { Has been } \\
\text { constructed in } \\
\text { reasonable } \\
\text { radius }\end{array}$ & $\begin{array}{l}\text { On construction } \\
\text { in reasonable } \\
\text { radius }\end{array}$ & $\begin{array}{l}\text { In the five-year } \\
\text { immediate plan }\end{array}$ & $\begin{array}{l}\text { No } \\
\text { immediate } \\
\text { plan }\end{array}$ \\
\hline 3 & Transportation & $25 \%$ & $12.5 \%$ & $\begin{array}{l}\text { Relationship } \\
\text { with the public } \\
\text { transportation } \\
\text { system }\end{array}$ & $\begin{array}{c}\text { Near mass } \\
\text { transit hub } \\
(<500 \text { meters })\end{array}$ & $\begin{array}{c}\text { Near mass transit } \\
\text { hub } \\
(<1000 \text { meters }) \\
\text { or have } \\
\text { convenient } \\
\text { public transit } \\
\text { condition }\end{array}$ & $\begin{array}{c}\text { Have } \\
\text { semi-convenien } \\
\text { t public transit } \\
\text { condition }\end{array}$ & $\begin{array}{l}\text { Have no } \\
\text { public transit } \\
\text { access }\end{array}$ \\
\hline \multirow{3}{*}{4} & \multirow{3}{*}{$\begin{array}{l}\text { Employment } \\
\text { environment }\end{array}$} & \multirow{3}{*}{$25 \%$} & $12.5 \%$ & $\begin{array}{l}\text { Relationship } \\
\text { with the city } \\
\text { road system }\end{array}$ & $\begin{array}{l}\text { Surrounding } \\
\text { road system has } \\
\text { become a } \\
\text { network }\end{array}$ & $\begin{array}{l}\text { Some of the roads } \\
\text { have been built, } \\
\text { some in the } \\
\text { five-year } \\
\text { immediate plan }\end{array}$ & $\begin{array}{l}\text { Some in the } \\
\text { five-year } \\
\text { immediate plan, } \\
\text { some in the } \\
\text { long term } \\
\text { plan }\end{array}$ & $\begin{array}{l}\text { All in the } \\
\text { long term } \\
\text { plan }\end{array}$ \\
\hline & & & $12.5 \%$ & $\begin{array}{l}\text { Second } \\
\text { industry }\end{array}$ & $\begin{array}{l}\text { Directly near } \\
\text { the industry } \\
\text { park } \\
\text { Near the city }\end{array}$ & $\begin{array}{l}\text { Near the } \\
\text { industry park } \\
(<20 \text { minutes } \\
\text { bus ride }) \\
\text { In certain need }\end{array}$ & $\begin{array}{l}20-45 \text { minutes } \\
\text { bus ride to } \\
\text { industry park }\end{array}$ & $\begin{array}{l}\text { No } \\
\text { appropriate } \\
\text { employment } \\
\text { No }\end{array}$ \\
\hline & & & $12.5 \%$ & $\begin{array}{l}\text { Tertiary } \\
\text { industry }\end{array}$ & $\begin{array}{l}\text { Center or } \\
\text { District center } \\
\text { in need of } \\
\text { low-skill } \\
\text { services }\end{array}$ & $\begin{array}{c}\text { Of low-skill } \\
\text { services }(<20 \\
\text { minutes bus ride })\end{array}$ & $\begin{array}{l}20 \text { - } 45 \text { minutes } \\
\text { Bus ride to } \\
\text { center }\end{array}$ & $\begin{array}{l}\text { Appropriate } \\
\text { employment }\end{array}$ \\
\hline
\end{tabular}

specific layout of affordable housing should be based on the community structure defined by the regulatory plan. To promote social interaction and to avoid 
closed large-scale islands, appropriate scale of the affordable housing within the community should be controlled. We established a community structure pattern in the special plan for affordable housing in Luhe District, Nanjing. As we can easily have seen in the pattern 1 of affordable housing and pattern two of common commercial housing See Figure 7.

In a community (about 30,000 inh), affordable houses should be mixed with commercial houses, the majority of which should be common commercial houses.

Such as the case in Dallas called Esperanza del Sol is using energy efficiency to make housing more affordable Daylighting and superior ventilation also give the houses a note of beauty and comfort [9].

In the pattern, the scale of the population of affordable houses shouldn't exceed one half of the population of the whole community, and the scale of the land area of affordable houses shouldn't exceed $40 \%$ of the land area of the whole community. Under the guidance of the principle, the layout of the affordable houses in the special plan for affordable housing of Nanjing LUHE reflected an appropriate dispersion of the affordable housing and a mixed community structure, an expanded use of the planning system to promote affordable housing [10]. See Figure 8.

- Establish landuse

Regulations on these sites detailed rules and regulations on those affordable housing sites should be set linked with the regulatory plan. In this level of plan system, the location, land area, the floor area ratio, and other technical and economic targets should be determined. Throughout the detailed rules and regulations linked with the regulatory plan, the location and layout of the affordable houses can obtain the legal.

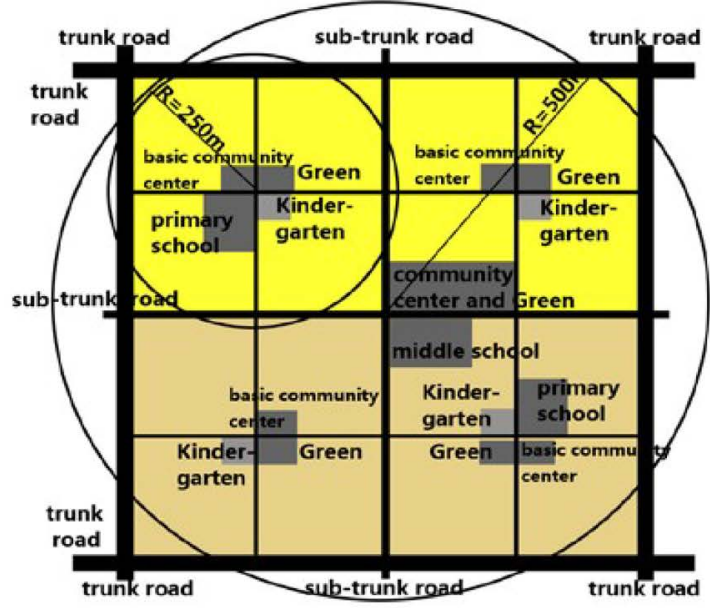

Pattern 1

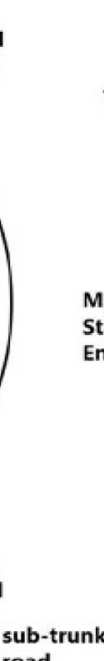

sub-trun
road

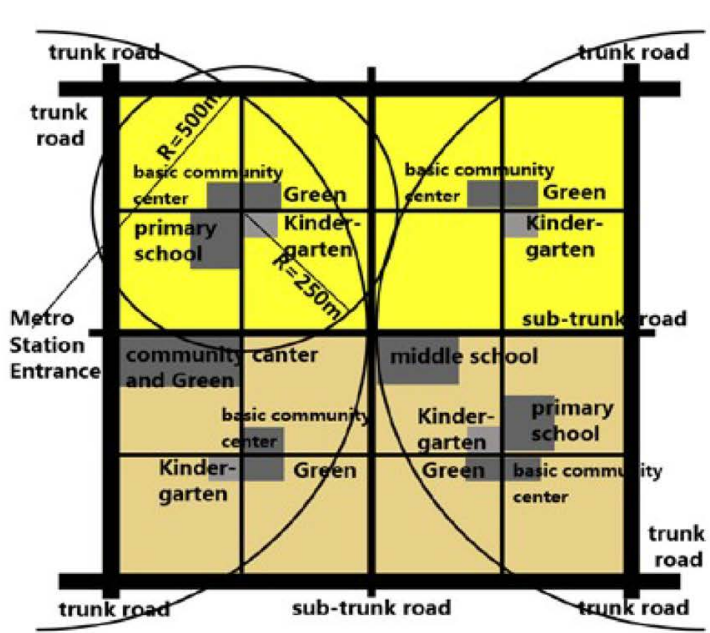

Pattern 2

\section{affordable houses}

common commercial houses

Figure 7. A varied public structure pattern. 


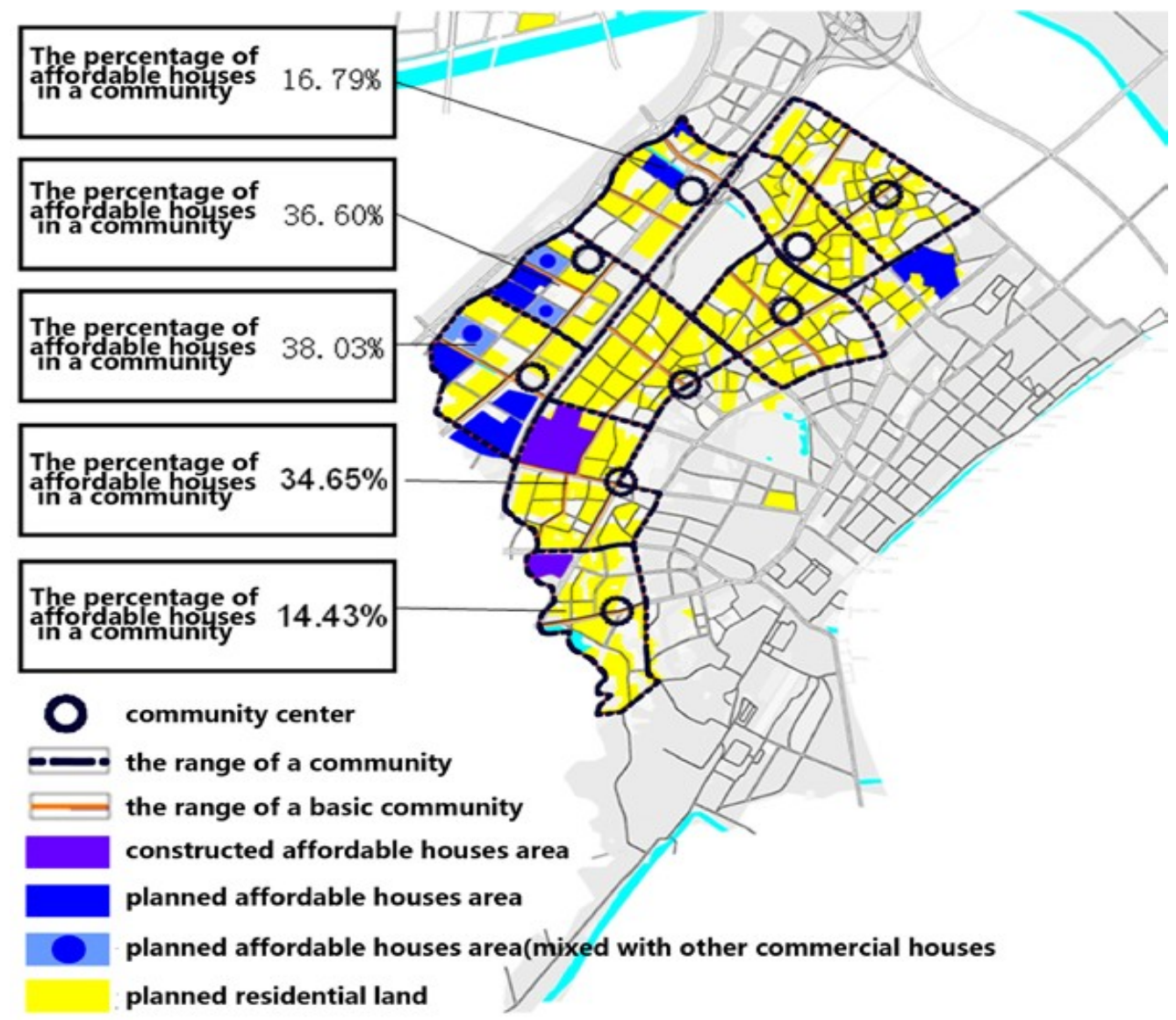

Figure 8. The planned community structure of Getang New Town, LUHE, Nanjing.

\section{References}

[1] Morrison, W.M. (2014) China's Economic Rise: History, Trends, Challenges, and Implications for the United States. Current Politics and Economics of Northern and Western Asia, 23, 493.

[2] Liang, Z. and Ma, Z. (2004) China's Floating Population: New Evidence from the 2000 Census. Population and Development Review, 30, 467-488. https://doi.org/10.1111/j.1728-4457.2004.00024.x

[3] Kogut, B. and Zander, U. (1996) What Firms Do? Coordination, Identity, and Learning. Organization Science, 7, 502-518. https://doi.org/10.1287/orsc.7.5.502

[4] Chen, F. and Korinek, K. (2010) Family Life Course Transitions and Rural Household Economy during China's Market Reform. Demography, 47, 963-987. https://doi.org/10.1007/BF03213735

[5] Massey, D.S., Albright, L., et al. (2013) Climbing Mount Laurel: The Struggle for Affordable Housing and Social Mobility in an American Suburb. Princeton University Press, New Jersey.

[6] Weaver, R.K. and Rockman, B.A. (2010) Do Institutions Matter? Government Capabilities in the United States and Abroad. Brookings Institution Press, Washington DC.

[7] Batty, M. (2013) The New Science of Cities. MIT Press, MIT.

[8] Binder, C.R., Feola, G., et al. (2010) Considering the Normative, Systemic and Pro- 
cedural Dimensions in Indicator-Based Sustainability Assessments in Agriculture. Environmental Impact Assessment Review, 30, 71-81.

https://doi.org/10.1016/j.eiar.2009.06.002

[9] Roodman, D.M., Lenssen, N.K., et al. (1995) A Building Revolution: How Ecology and Health Concerns Are Transforming Construction. Worldwatch Institute, Washington, DC.

[10] Gurran, N., Milligan, V., et al. (2008) New Directions in Planning for Affordable Housing: Australian and International Evidence and Implications. Research and Policy Bulletin, No. 1-143, 105. 